\title{
The Prevalence of the Song Tea Bowl Among Japanese Elites in the Kamakura and Early Muromachi Period
}

\author{
Yian Ren* \\ College of Arts and Science, New York University, New York City, NY 11101, China \\ *Corresponding author. Email: yr854@nyu.edu
}

\begin{abstract}
Since the Buddhist monk Myōan Eisai reintroduced tea culture from China to Japan during the early Muromachi period, it had become popular among the Japanese elite class. According to many historical records, Japanese elites have adopted the Song tea bowl as their tea utensils before the wabi and sabi formula dominated the tea culture in Japan in the late Muromachi period. This paper will take a look at the application of the Song tea bowl to tea drinking settings in Japan from the early Kamakura to the late Muromachi period and analyze the reason why it could prevail among the Japanese elite class from the political, economical and aesthetic aspects. Its prevalence unveils the social situation and the aesthetic preference at that time and reflects some of the cultural traditions of Japan.
\end{abstract}

Keywords: Japanese tea ceremony, Song tea bowl, Zen aesthetics.

\section{INTRODUCTION}

The Japanese tea ceremony, chado, is recognized as an important element of Japanese culture. During the latter years of the Muromachi period, the modern chado began to take shape under the influence of the wabi tea masters like Murata Jukō (1423-1502) and Sen no Rikyū (1522-1591). However, before the invention of wabi tea, the tea ceremony had already prevailed in Japan since the early Kamakura period, when the Buddhist monk Myōan Eisai (1141-1215) reintroduced the tea culture from Song China to Japan. Eisai advocated that Buddhism has its responsibilities on the country's welfare and promoted the tea ceremony as a ritual practice of the religion[1]. The tea ceremony quickly spread through the elite class in Japan. It can be discovered from historical evidence that the Japanese elites favored collecting and using the Song tea bowl for centuries before the wabi tea values dominated the tea culture and ceramic production in Japan in the late sixteenth century. This paper will discuss by whom the Song tea bowl was used and collected and examine why it prevailed in Japan before the invention of wabi tea. Based on the research, the elite class in Japan, including the Buddhist monks, the aristocrats, and the highranking samurai, were the primary consumers of the bowl. The political function, economic value, cultural prestige, and aesthetic appeal of the Song tea bowl have contributed to its popularity among the elite class from the early Kamakura to the latter Muromachi period.

\section{ANALYSIS OF THE HISTORICAL EVIDENCE}

The Song tea bowl, as an import from China, was available to only a limited number of elites in medieval Japan. After the official connection between Japan and Tang China stopped in $894 \mathrm{CE}$, the foreign trading ships were under the strict control of Dazaifu during the end of the Heian period. They were only allowed to land on the Japanese archipelago once every few years[2]. Only the ruling class had access to foreign products at that time. However, due to the loosening regulation from the Japanese officials, more private merchant ships were able to arrive at Japan, seeking opportunities to trade with wealthier customers in different regions. It came to the age of "magnate trade", referred to as Kenmon Bōeki by some Japanese historians[2]. The term Kenmon, as defined by the scholar Richard Von Glahn, refers to "the great proprietors of landed estates"[2], which include the imperial family, aristocrats, Buddhist monasteries, shrines, and high-ranking samurai including the shogun. These groups of the elite class had access to Chinese imports like the Song tea bowls in early medieval Japan. Before the market for the exchange of foreign goods emerged in the fourteenth century, the Chinese merchants could only sell their products relying on 
powerful agents[3]. The agents, who usually belonged to monasteries or shrines, encouraged the competition between the magnates and permitted them to bid up the prices to get a higher agency fee or to solidify their bonds with merchants. The formidable prices excluded the vast majority of the population from collecting and using the Song tea bowl and limited its circulation only among the wealthy elites.

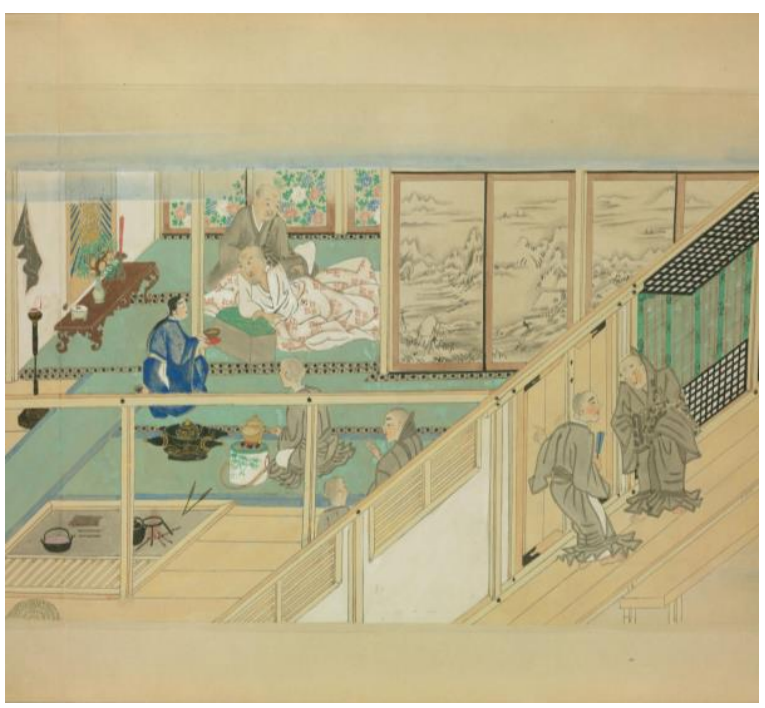

Figure 1 Fujiwara, Takaa, Fujiwara, Takam. \& Fujiwara, H. Nanboku-chō period (1336-1392), Boki Ekotoba Scroll No.10, 1351, Nishi Honganji Temple, Kyoto. National Diet Library Digital Collection. https://dl.ndl.go.jp/info:ndljp/pid/2590848

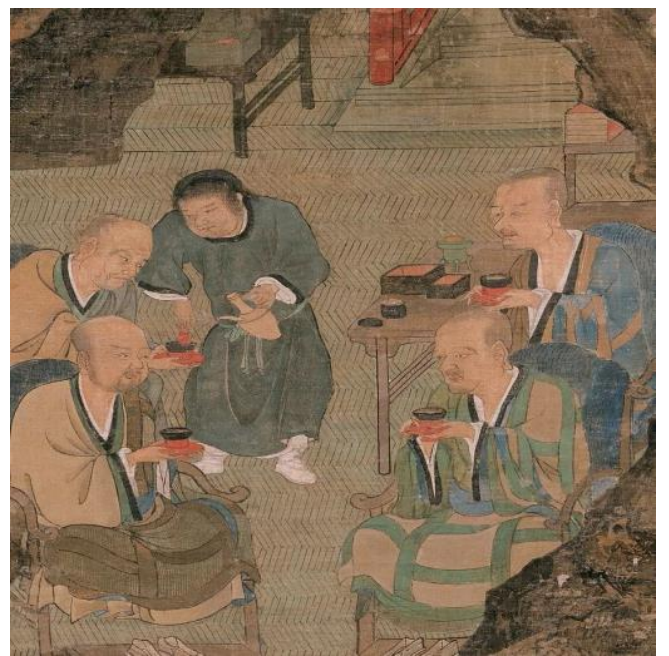

Figure 2 Lin T.G. and Zhou J.C., Southern Song Dynasty (1127-1279), Kissa section of The Five

Hundred Arhats, Daitokuji temple, Nara. http://urasenke.or.jp/textc/gallery/tenji/index.html

Among all the possible users in medieval Japan, the Buddhist monks applied the Song tea bowl in many settings in their life. With the effort of the Buddhist priests like Eisai and Myōe, the tea ceremony spread through the Buddhist monasteries. In many tea-drinking settings, we can observe the existence of the Song tea bowl through some pictorial evidence. For example, in the tenth scroll of the painting Boki Ekotoba (Figure 1), it depicts the Buddhist priest Kakunyo (1271-1351) leaning on the tatami and receiving a bowl of tea from a retainer dressed in blue. The tea bowl and the tea bowl stand held in the retainer's hands are in a color combination of red and black. Such a combination often appeared in the Song depictions of tea-drinking as well, such as The Five Hundred Arhats painted in the Southern Song Dynasty (1127-1279 CE). In the kissa section of The Five Hundred Arhats (Figure 2), four monks gathered around in a garden and each held a combination of a red tea bowl stand and a black tea bowl. As mentioned in the book Treatise on Tea (1107), the Huizong Emperor of Song China (1082-1135) praised the tea bowl in a dark bluish-black color to be ideal for tea drinking[4]. His text confirmed the popularity of such tea bowls in Song society, which were mainly produced in the Fujian province in China and exported to Japan through trading activities. They were largely welcomed by Japanese elites after entering Japan, especially by the Buddhist monks. Boki Ekotoba shows a Buddhist priest using the Song tea bowl in a monastery in a leisurely way. The Song tea bowl also appeared in different social settings used by not only the Buddhist monks but also the other members of the elite class in medieval Japan.

The Song tea bowl also appeared in the social activities involving different members of the elite class. In a reproduction of the mid-16th century scroll painting Shuhanron Emaki, tea was prepared for the guests in a banquet at a countryside mansion. Banqueting was a social activity commonly held by the military, noble and monastic class to treat and entertain the guests in Muromachi Japan. In this case, the banquet welcomes guests from all three groups of the elite class: the courtier, the monk, and the high-ranking samurai[5]. In the food preparation section, a monk is blowing into the stove with water heating up in a kettle on the top (Figure 3 ). Next to him are multiple sets of white tea bowls and red tea bowl stands. The tea bowl stand is the same kind as the one shown in the Boki Ekotoba, and the white tea bowl, with its slender shape and plain decoration, looks similar to the whiteware produced in the northern part of Song China, such as the White-Glazed Tea Bowl (Ding Ware) (Figure 4) exhibited in the Palace Museum in Beijing. The tea serving was a necessary part of the banquet and in this depiction, the host chose the Song tea bowl combination to serve all the guests. We can see that the Song tea bowl was considered as a proper utensil served for decent guests in social activity. Its value was widely acknowledged by the elites. The aristocrats, the priests, and the high-ranking samurai all became the target users of the Song tea bowl in Muromachi Japan. 


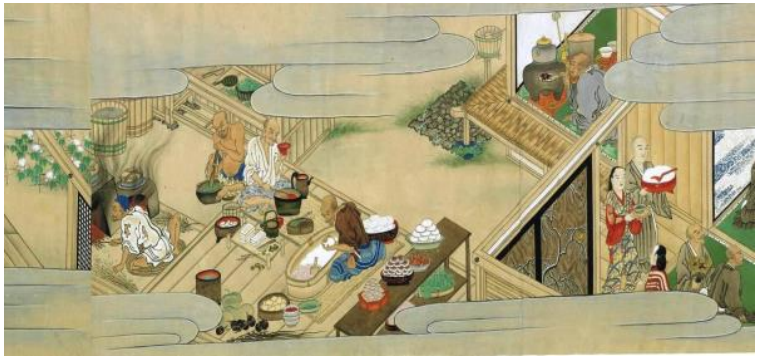

Figure 3 18th century, Service room and back room of the residence, Shuhanron Emaki, National Diet Library,

Tokyo. https://dl.ndl.go.jp/info:ndljp/pid/2542602

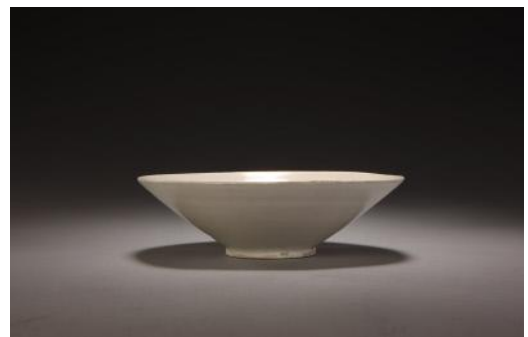

Figure 4 Five Dynasties and Ten Kingdoms period (907-979), White-Glazed Tea Bowl (Ding Ware),

Palace Museum, Beijing.

https://www.dpm.org.cn/collection/ceramic/228007.htm

1

In the late Muromachi period, the Song tea bowl has become a luxury item for the Japanese elites to include in their personal collections. The Kundaikan-sōchōki (1476), a catalog of the artworks displayed in the main palace of Higashiyama Sensō owned by Ashikaga Yoshimasa (1436-1490), has listed various types of the Song tea bowl (Figure 5). Yoshimasa constructed the Sensō for his retirement and gathered his most precious collection of artworks in the main palace. In the ceramic section of the catalog, it includes, for instance, the Yuteki, Tenmoku, and Jyōshī. Yuteki refers to the tea bowl with oil drop glaze produced in the Fujian Province in Song China (Figure 6); Tenmoku refers to the Song tea bowl with the natural pattern formed by the liquid iron in the glaze after cooling down (Figure 7); and Jyōshu (modern Jingdezhen), a renowned kiln that produced the celadons of Qingbai glaze during the Song dynasty (Figure 8). Each name represents a typical type of glaze of the Song tea bowl. According to the pictorial illustrations of the catalog, these bowls were displayed on the wooden shelf as a part of the noble treasure. They were cherished by the shogun and became a part of his personal collection that he was proud to display to his visitors. The appearance of the Song tea bowl in the private collection of the shogun marks the high value of the Song tea bowl during the Muromachi period.

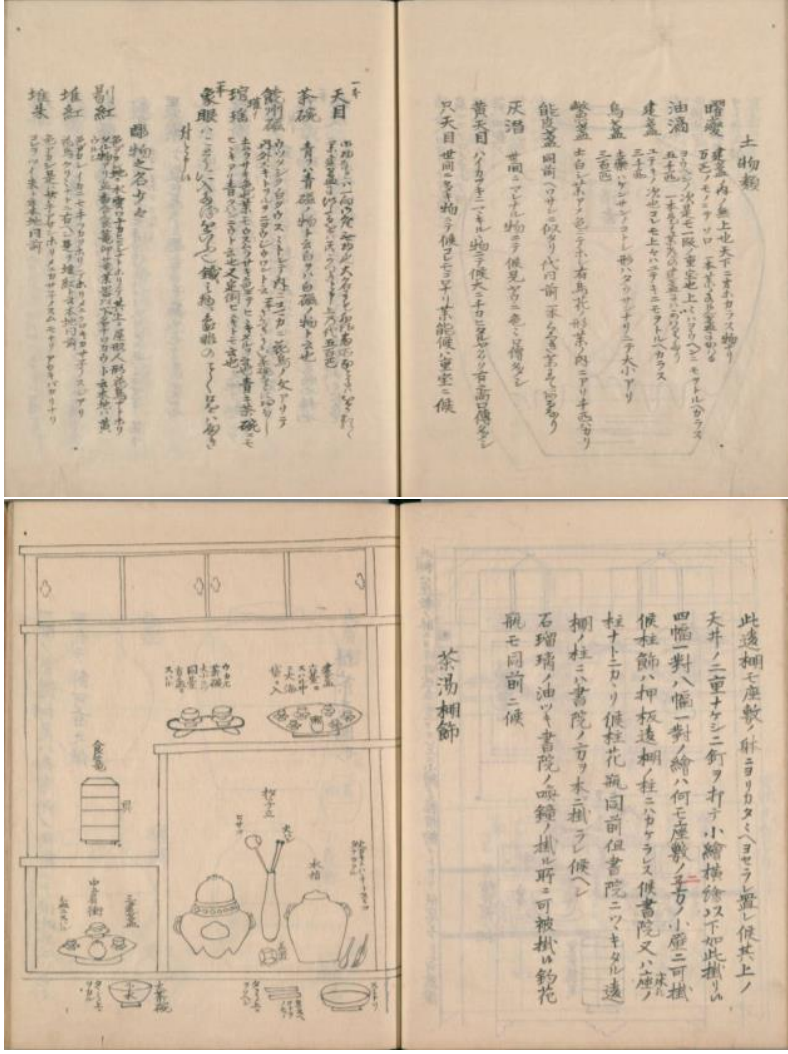

Figure 5 Nōami. Muromachi Period (1338-1573). The ceramic section and pictorial illustrations of Kundaikan sōchōki. National Diet Library, Tokyo. National Diet Library Digital Collection, https://dl.ndl.go.jp/info:ndljp/pid/2539239

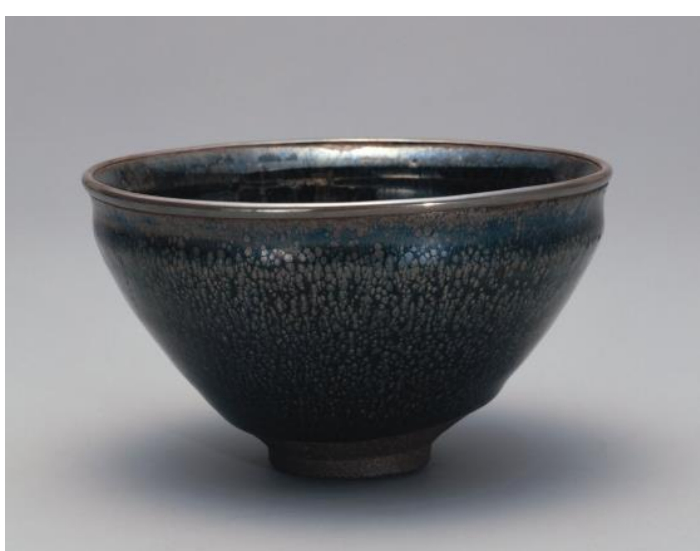

Figure 6 Northern Song Dynasty (960-1127), Jian Ware Tea Bowl with Oil Drop Glaze. The Tokugawa Art Museum, Nagoya.

https://artsandculture.google.com/asset/tea-bowl-yutekioilspot-tenmoku-type-known-as-hoshi-kensan-starpatterned-tea-bowl-jianzhan-kilnschina/mQGJCBAeVz-VlA?hl=ja 


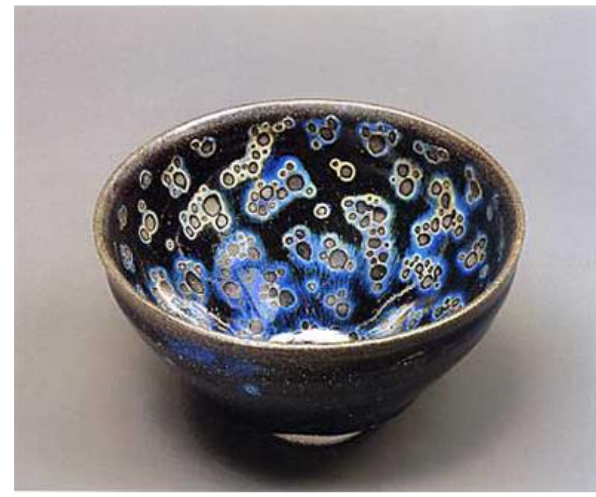

Figure 7 First half of the 15th century. Yōhen Tenmoku, Jian ware. Seikado Bunko Art Museum, Tokyo. http://www.seikado.or.jp/en/collection/\#collection--01

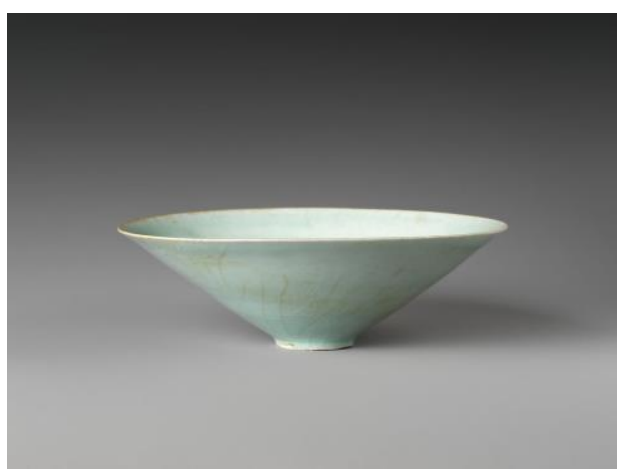

Figure 8 Song Dynasty (960-1279), Bowl (Raozhou Kiln, Qingbai Ware), Metropolitan Museum of Art, New York.

https://www.metmuseum.org/art/collection/search/4837

The popularity of Song tea bowls extended to the local ceramic production in Japan. Since the Song tea bowl became increasingly hard-to-get for its high price and short supply, many local kilns like the Seto kiln began to produce tea bowls in the Song style. The 16thcentury Seto Kiln product, Tea Bowl with Hare's-Fur Decoration (Figure 9), is one of the examples of the local kiln production of such style. Compared to the similar product produced by Jian Kiln in the Fujian province (Figure 10), it has a similar size and shape, the bluish-black glaze, the brownish stripes, and the rough inner clay exposed at the bottom. Because the imports from China could no longer satisfy the demand of the buyers, such locally produced tea bowls also gained popularity as substitutes for the Chinese ones.

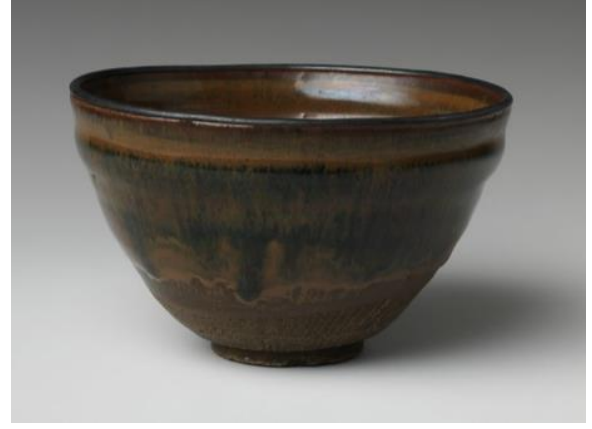

Figure 9 16th century, Tea Bowl with Hare's-Fur Decoration (Seto ware), Metropolitan Museum of Art, New

York .https://www.metmuseum.org/art/collection/search 145339

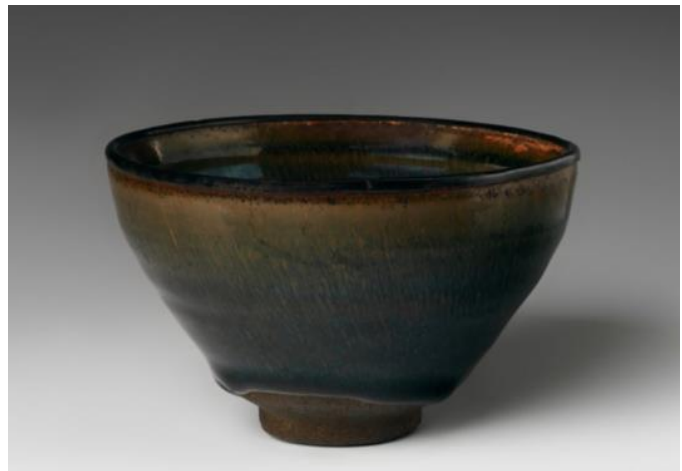

Figure 10 11th-12th century, Tea Bowl with Hare's-

Fur Decoration, Metropolitan Museum of Art, New York.

https://www.metmuseum.org/art/collection/search/5107 6

As we can see, many historical records have shown the popularity of the Song tea bowls among the Japanese elites. They were applied as tea utensils by the aristocrats, the Buddhist monks, and politically powerful figures in both private and public settings. From the early Kamakura to the Muromachi period, their preference has endured for centuries. The bowl was not purely regarded as a practical utensil but a luxury item for private collection during the later Muromachi era. The Song tea bowl was popular for its practical functions in the tea-drinking settings, but more importantly because it conveyed an extra message of the political and economic power, the cultural prestige, and the aesthetic tastes of the owner.

\section{DISCUSSION}

The Japanese elites viewed the Song tea bowl as a wealth symbol to demonstrate their financial capabilities. During the Kamakura period, as Dazaifu gradually lost its control over the private trading ships, the merchants turned to look for rich customers to earn greater profits, which triggered price booming and encouraged competition between the buyers. People who got the 
opportunity to trade with the merchants and had access to foreign goods were proved to be more economically powerful than those who were not able to get them. In the Muromachi era, the tributary connection between Japan and Ming China was inaugurated under the effort of Ashikaga Yoshimitsu (1358-1408), the third shogun of the Ashikaga shogunate, to secure Bakufu's financial profits. If the Bakufu controlled the trade and had the priority to get Chinese goods, it could earn more financial gain since the Chinese imports were at a high price in Japan. The value of these goods can be seen from the evidence showing that violent disputes arose when the Japanese traders found that the officially set prices for non-tribute goods were too low[6]. The high value of the Chinese goods including the Song tea bowl made the Japanese elites purchase and collect them to prove they won the competition and to show off their wealth.

The Song tea bowl also worked for political figures to signify their political power in medieval Japan. During the early twelfth century, the Taira gradually gained control of the maritime trading routes and became the primary administrators of foreign trade[7]. However, other strong clans, such as the Fujiwara family, tried to interfere in the monopoly of Taira and sought opportunities to trade with these foreign merchants. It turned out that more merchants were inclined to the Fujiwara for their financial wealth[7]. By their dominance in foreign trade, the Fujiwara were able to declare their political influence and economic power over the Taira. The archaeologists have discovered a large number of celadon shards from the Hiraizumi Mansion of the Fujiwara family[7]. The ownership of the foreign goods helped to demonstrate their privilege and to signify their political status. When the time came to the Muromachi period, by reestablishing the tributary connection with Ming China, Ashikaga Yoshimitsu not only gained the financial profits but also received a political legitimization that he was entitled to "King of Japan" by the Ming government[7]. He used Chinese objects to reinforce his title and the political legitimacy to rule over the country. The Song tea bowl became a tool for Japanese elites to signify their political status, proving their ability to control foreign trade or legitimize their rule.

The Song tea bowl not only politically and economically facilitated the elites to state their power but also brought them cultural prestige. Two figures primarily influenced their view on the Song tea bowl. The first figure was the Huizong Emperor of the Song Dynasty in China. He wrote a book on tea culture, Treatise on Tea, and expressed his preference for the Song tea bowl in the book. The Huizong Emperor was venerated as a cultural icon and a model ruler by the Kamakura and Muromachi rulers[8]. Among all the followers, Ashikaga Yoshimitsu might be the fanatic one. He even asked a priest to copy verbatim Dahui
Zonggao's (1089-1163) inscription on Huizong's portrait to Yoshimitsu's own portrait, which was rarely done by the shoguns[8]. By emulating Huizong's cultural practice and art collection, including the practice of tea ceremony and the favor of the Song tea bowl, the rulers were able to liken themselves to the cultural model and declare their cultural inheritance. The other important figure was the Zen master Musō Soseki (1275-1351), who was the advisor of the Tennō, the shogun, and many Buddhist priests. As a representative of Gozan Bungaku, he devoted himself to learning the Song texts, including the Neo-Confucianist works. He denied the casual way of tea drinking but advocated the traditional Song customs of tea ceremony[1]. By his teaching, Musō was able to spread the Song customs among the elite class. The Song tea bowl, along with the Song customs, was welcomed by the elites to build their cultural images and earn a cultural prestige.

Besides the political, economic and cultural factors, the aesthetic appeal of the Song tea bowl played an important role in its prevalence among the Japanese elites. The old Heian literature like The Pillow Book (1001) and The Diary of Lady Murasaki (1008-1010) had expressed some aesthetic values that were shared by the Song tea bowl. These values might set the basis for the favor of the Song tea bowl in medieval Japan. By their descriptions, the authors of the two Heian works revealed the preference for aesthetic qualities in the old Heian court, such as purity, cleanness, and the beauty of dark-and-bright color contrast. For example, in The Pillow Book, Sei Shōnagon listed "Things that look fresh and pure": "Earthenware cups. Shiny new metal bowls. Rushes to be used for making mats. The transparent light in water as you pour it into something. [9]" In Heian court, the earthenware cup was discarded after each use. Shōnagon praises the unused ones in the book but people were unbearable for filth and dirt. These objects were all distinguished for being unadorned and pure. She found them refreshing and worth appreciating. Murasaki Shikibu, in her diary, also expresses her appreciation for being pure and clean. She gives a description that "[f]or seven nights every ceremony was performed cloudlessly. Before the Queen in white the styles and colours of other people's dresses appeared in sharp contrast. It seems hair growing in good monochromatic picture.[10]" Murasaki, in this quote, assimilates the scene of the queen dressed in white under the moonlight as a monochrome painting. The Heian court had a high opinion on the beauty of monochrome paintings which used a limited palette to delineate its subject. The queen is dressed without vibrant decorative patterns, and the bright color clothes of the attendants contrast against the queen being pristine. By praising such a scene as a monochrome painting, Murasaki expresses her appreciation for the pureness of the queen and her admiration of monochrome pictures. From these two works, we can 
see that being pure and clean was considered beautiful and admirable in the Heian court. We can find these qualities in the Song tea bowl as well. The Tea Bowl (Longquan Glaze) (figure 11) in the Metropolitan Museum of Art best exemplifies these qualities. It is evenly glazed with a light green color and without complex decorative patterns. It can hardly be discovered any crackles or bubbles in the glaze. Its flawless appearance and monochrome color fit into the purity and cleanness mentioned in the Heian court literature. The celadon shards found in the Hiraizumi Mansion of the Fujiwara family were in a similar kind of the Longquan bowl. The historical traceback of the fascination of the Song tea bowl for their purity and cleanness can be found in the Heian era.

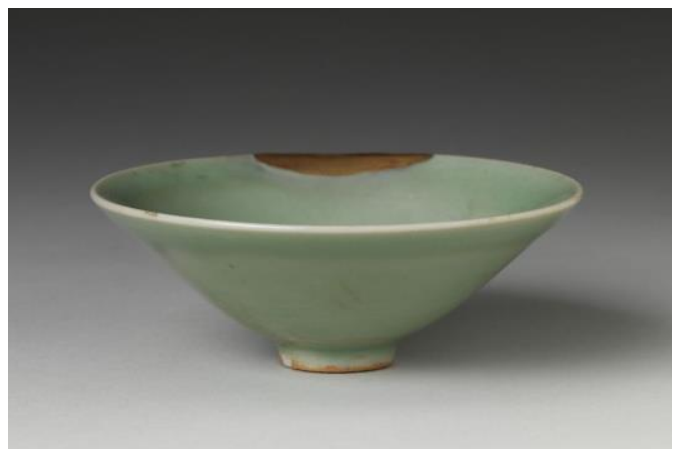

Figure 11 Southern Song dynasty (1127-1279), Tea bowl (Longquan Glaze), Metropolitan Museum of Art, New York.

https://www.metmuseum.org/art/collection/search/4837 3

Moreover, in The Pillow Book, Shōnagon has mentioned the beauty of dark-and-light color contrast many times. In the section "Flowering Trees", Shōnagon wrote: "At the end of the Fourth Month and the beginning of the Fifth the orange trees have dark green leaves and are covered with brilliant white flowers. In the early morning, when they have been sprinkled with rain, one feels that nothing in the world can match their charm.[11]" She was attracted to the white flowers blooming in between the dark green leaves. The color contrast visually appeals to her and gives her a refreshing mood in the rain. Her appreciation of the color contrast also appeared when she talked about picking horses: "In horses, very black ones with just a little white somewhere are special. Also those with chestnut markings, speckled greys, strawberry roans with very white manes and tails - the expression 'wand paperwhite' is indeed an appropriate one here.[11]" The black-fur horse with a few hairs in white was regarded as a special one, and those with grey or brown furs interspersed within were praised as well. The decorative patterns on the Song tea bowl echoed with the description of the horse's fur by Shōnagon, such as the Tea Bowl with Hare's-Fur Decoration (Figure 10). The artisans in Fujian incorporated fur-like patterns in their products. In this case, the bowl is decorated with yellowish-brown minute stripes on the dark bluish-black background. The color of the decorative pattern varied between different bowls. Some were in the yellowishbrown color, and others could be in silver, grey, blue, or gold, depending on the temperature in the kiln and the composition of the glaze. This diversity of colors against the dark background conformed to the description written by Shōnagon. The shared aesthetic preference established the connection between the two different historical periods. The aesthetic qualities of the Song tea bowl that were preferred by the elites in medieval Japan might have their origin back in earlier times.

Although the aesthetic influence from the old Heian court might contribute to their preference of the Song tea bowl, the Zen values would be the primary factors that shaped the aesthetic tastes of Japanese elites and led to their fascination with the Song tea bowl. When Eisai introduced tea ceremony to Japan in the early Kamakura era, it was promoted as a ritual practice of Zen Buddhism. With the help of the shogun Minamoto no Sanetomo (1192-1219), Eisai and other Zen priests were able to spread Zen Buddhism among the elite class[1]. The Japanese elites acknowledged the significance and the essence of Zen, and Zen values by then have influenced the arts and aesthetics throughout Japan. Since the Song tea bowl in many ways fit into the Zen aesthetics, the elites incorporated the object into their lives.

Zen aesthetics highly regard the quality of nature. As defined by the Zen Buddhist scholar Hisamatsu Shin'ichi (1889-1980), being natural means "not being artificial", being "unrestrained", or having "no mind" or "no intent"[12]. For the Tea Bowl with Hare's-Fur Decoration (Figure 10), the iron contained in the glaze mixture naturally drips down in the high temperature and forms natural stripes and spots. The clay is exposed at the bottom as the thick glaze naturally flowing down never reaches the foot of the bowl. The potter did not intentionally control how the glaze would flow but kept the original form as it went from a natural process. The reduced human force involved in this process matches an unconstrained natural state preferred by Zen.

Another aesthetic quality strengthened by Zen is simplicity. When Hisamatsu talks about simplicity in his book Zen and the Fine Art (1971), he approves simplicity in Zen equivalent to "having nothing limiting" and "abandoning", which partly overlaps with the concept of nature. He denies the deliberateness and regards being unlimiting as a representation of simplicity. He adds that "simplicity in color means that colors are unobtrusive and that diversity is avoided.[12]" The Song tea bowl embodies spontaneity and modest coloring, such as the Tea bowl (Longquan Glaze) (Figure 11). It has no painted decorative patterns and is 
evenly glazed with a light green color. The lightly glazed ware has a calming effect and never shines out in a disturbing way. In the glaze, there are many naturally formed bubbles and crackles. No deliberate human force was involved to diminish these "faults" or control the final presentation. This fits into the favor of simplicity in Zen described by Hisamatsu.

Zen Art also praised the quality of irregularity. In his book The Zen of Creativity: Cultivating Your Artistic Life (2005), the Zen Buddhist priest John Daido Loori (1931-2009) points out that Zen Art prefers representations that are "jagged, gnarled, irregular, twisting, dashing, sweeping.[13]" Hisamatsu also explains that in Zen aesthetics, "being irregular means being crooked or unbalanced.[12]" Zen Art is inclined to asymmetrical shapes and patterns without an order. For the Hare's-Fur kind of the Song tea bowl (Figure $10)$, the liquid iron forms an unpredictable pattern in the glaze. People fancied such unpredictability and developed many different types of decorative patterns by adjusting the composition of the glaze. The patterns of Yuteki, Tenmoku, and Taimai (lit. Hawksbill sea turtle) (Figure 12) were the variations made for the Song tea bowl. They were all distinguished by their diversity of colors and patterns. People would never be able to know its final presentation until the bowl came out from the kiln. The unpredictability and mysteriousness of the Song tea bowl made the Song tea bowl unique in its appearance and appealed to Japanese people. As we can see, the Song tea bowl has in many ways fits into the Zen aesthetics and became widely used by the elite class in Japan, who embraced Zen Buddhism and incorporated Zen values into their lives.

Furthermore, the local kilns have adapted the preexisting style of pottery making for the production of tea bowls in medieval Japan. As the tea ceremony became popular in Japan, the demand for tea bowls has been increasing. The imports from China could no longer satisfy the needs of the buyers. The supply shortage prompted the local kilns to produce local tea bowls for substitution. Some of these bowls were in the Song style as mentioned above, but there was a small number of potteries derived from earlier styles that originated locally. The tea bowl in the yellow Seto style is one of the examples (Figure 13). The bowl displays some of the aesthetic elements that we can see from the Song tea bowl. It also has a plain decorative pattern and a glaze of light color. The glaze naturally drips down and could not fully cover the inner clay at the bottom. It stays in a primitive way with less human force involved in its decoration. We can see from the local products that the Zen aesthetic preferences like nature and simplicity were widely admired and appreciated. Such wide appreciation contributed to the popularity of the Song tea bowl, which displayed these qualities in a refined way.

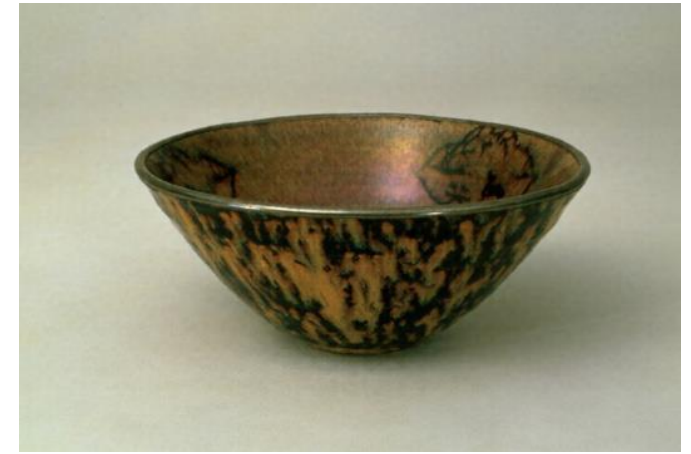

Figure 12 Southern Song dynasty (1127-1279), Taimai Tenmoku Tea Bowl, The Tokugawa Art Museum, Nagoya. https://bunka.nii.ac.jp/heritages/detail/71152

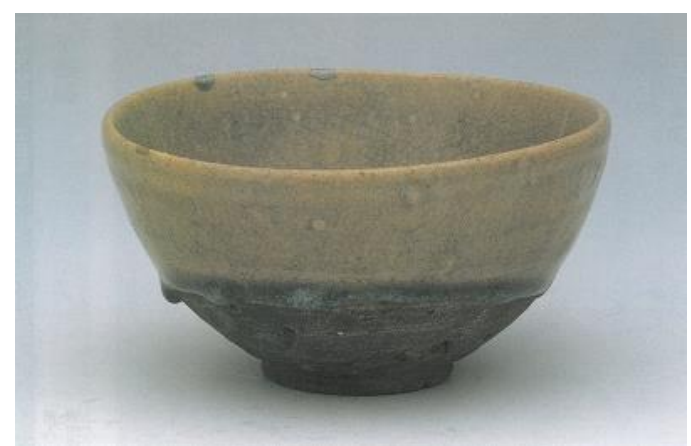

Figure 13 Kousui Takugeikan, Muromachi Period (1336-1573), Pottery Yellow-Seto Tea Bowl, Search Site of Cultural Asset of Yamagata https://www.pref.yamagata.jp/cgi-bin/yamagatatakara/?m=detail\&id=1357

\section{CONCLUSION}

In conclusion, multiple factors must be taken into consideration when we look at the popularity of the Song tea bowl among the elite class in medieval Japan. The bowl was not only accepted for its practical function but also appreciated for the political message it carried, its economic value, cultural power and aesthetic appeal. It became a symbol to demonstrate the political power and financial capability of the owner and helped to build a positive cultural image. Also, the aesthetic qualities embodied in the Song tea bowl corresponded with the old Heian values and Zen beliefs, which might contribute to the widespread usage of the objects. The prevalence of the Song tea bowl reflects the social and cultural environment and reveals the aesthetic preference at that time. It has become the key for modern people to unlock the lives of Japanese elites from the early Kamakura to the Muromachi period.

\section{REFERENCES}

[1] Theodore, M. L. (1981) Before Rikyū. Religious and Aesthetic Influences in the Early History of the Tea Ceremony. Monumenta Nipponica, XXXVI, 4, 368-390 
[2] Glahn, R. (2014) The Ningbo-Hakata Merchant Network and the Reorientation of East Asian Maritime Trade, 1150-1350. Harvard Journal of Asiatic Studies 74, no. 2 : 249-79.

[3] Li, Y. (2021), Integrating Faith And Profit: The Religio-Commercial Network Spanning China And Japan, 1100-1270. Journal Of The Economic And Social History Of The Orient 64 (3): 191-216.

[4] Zhao, J. (2016), Treatise On Tea, Archive.Globalteahut.Org.

http://archive.globalteahut.org/article/694.

[5] von Verschuer, C. (2017), Illustrated Debate Over Wine And Rice (Shuhanron Emaki): Dining And Socializing In Late Muromachi Japan. Monumenta Nipponica 72 (2): 189-222.

[6] Grossberg, K.A. (2001), Japan's Renaissance. Ithaca (N.Y.): Cornell University.

[7] Yiengpruksawan, M.H.(1998), Hiraizumi: Buddhist Art and Regional Politics in Twelfth-Century Japan. Cambridge, Massachusetts; London: Harvard University Asia Center.

[8] Lippit, Y.(2012), Of Modes and Manners in Japanese Ink Painting: Sesshū's "Splashed Ink Landscape" of 1495, The Art Bulletin 94, no. 1: 50-77.

[9] Shonagon. S, Meredith M., (2007). The Pillow Book. New York: Penguin Classics [Imprint].

[10] Murasaki, S., Amy L., Annie S. O., and Kochi D. (2019). The Diary Of Lady Murasaki. Newburyport: Dover Publications.

[11] Morris, I., and Shōnagon S.(2018). The Pillow Book. New York: Columbia University Press.

[12] Hisamatsu, S. (1982), Zen And The Fine Arts. New York: Kodansha International.

[13] Loori, J. D. (2005), The Zen Of Creativity. New York: Ballantine Books. 